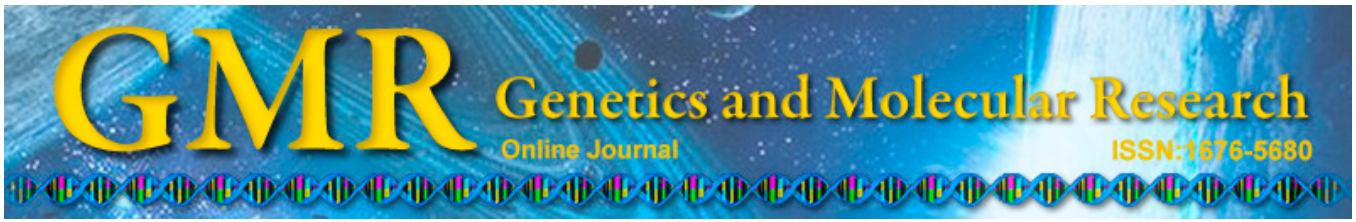

\title{
Fragmentation effects and genetic diversity of the key semidecidual forest species Metrodorea nigra in Southwestern Brazil
}

\author{
R.M. Moraes Filho ${ }^{1,2}$, F. Bonifácio-Anacleto ${ }^{1}$ and A.L. Alzate-Marin ${ }^{1,2}$ \\ ${ }^{1}$ Laboratório de Genética Vegetal, Departamento de Genética, \\ Faculdade de Medicina de Ribeirão Preto, Universidade de São Paulo, \\ Ribeirão Preto, SP, Brasil \\ ${ }^{2}$ Programa de Pós-Graduação em Genética, Universidade de São Paulo, \\ Ribeirão Preto, SP, Brasil \\ Corresponding author: A.L. Alzate-Marin \\ E-mail: anaalzate@fmrp.usp.br
}

Genet. Mol. Res. 14 (2): 3509-3524 (2015)

Received June 10, 2014

Accepted October 20, 2014

Published April 15, 2015

DOI http://dx.doi.org/10.4238/2015.April.15.15

\begin{abstract}
Studies of genetic diversity in plant species present in the remaining fragments of the Atlantic Forest are very important for understanding their resilience to such a degraded ecosystem. We analyzed the genetic diversity of 3 populations of the high-density understory species Metrodorea nigra St. Hill. (Rutaceae) located in forest remnants in the region of Ribeirão Preto, SP, Brazil (M13-Rib, BSQ-Rib, and FACCrav), by using simple sequence repeat (SSR) and inter-simple sequence repeat (ISSR) molecular markers for conservation purposes. A total of 133 polymorphic loci were observed in 136 inter-simple sequence repeat loci (average of 17 per primer). The Nei genetic diversity $\left(H_{\mathrm{E}}\right)$ was relatively high considering all populations ( 0.31$)$. The BSQ-Rib population exhibited the highest value (0.27), followed by the M13-Rib (0.26) and FAC-Crav $(0.24)$ populations. The simple sequence repeat markers analyzed showed a high number of alleles $(\mathrm{K}=104)$, with an average of 14.85 alleles per locus. The average observed heterozygosity was 0.516 and the average
\end{abstract}


expected heterozygosity was 0.771 , ranging from 0.688 (FAC-Crav) to 0.765 (BSQ-Rib). The fixation indexes showed positive and significant differences from zero for all sample sets, indicating inbreeding, which may have resulted from the species' mating patterns and the barochoric seed dispersal system of $M$. nigra. Both markers indicated differentiation among populations, with higher values observed for inter-simple sequence repeat markers. No significant differences between juvenile and adult generations in any of the fragments were observed, indicating the resilience of $M$. nigra to the effects of fragmentation and reduced habitat.

Key words: Carrapateira; Population genetics; Rutaceae;

Simple sequence repeat marker; Inter-simple sequence repeat marker; Tropical forest species

\section{INTRODUCTION}

Habitat fragmentation is one of the major challenges in the conservation of biological diversity worldwide (Andrén, 1994). By the beginning of the 21st century, the Atlantic forest had been severely reduced and fragmented, restricted to approximately $98,000 \mathrm{~km}^{2}$, or $7.6 \%$ of its original constitution (Morellato and Haddad, 2000). The deforestation and fragmentation of tropical forests have been intensely studied in recent decades. Much of the remaining forest cover is under intense anthropogenic pressures in fragments with less than 50 ha (Ribeiro et al., 2009). The suppression of native vegetation by agricultural activities and urban expansion as well as indiscriminate extraction, resulted in extreme fragmentation of the forest ecosystems in the Ribeirão Preto region in southwest Brazil (Kotchetkoff-Henriques, 2003), drastically reducing forest genetic resources.

Aguilar et al. (2008) recommended focusing on conservation efforts in fragmented environments for common and cross-pollinating species, to facilitate the understanding how fragmentation impacts these species over time. We examined the species Metrodorea nigra A. St.-Hill, a perennial tree of the Rutaceae family, which is frequently found in the Brazilian submontane semideciduous forests from the state of Paraná to Bahia (Souza et al., 2004). Many characteristics of this species, such as anatomy and morphology (Souza et al., 2004, 2008), floral biology, phenology, breeding systems, and flower visitors (Pombal and Morellato, 2000), have been extensively studied. Small brownish violet or dark purple flowers with an unpleasant smell are observed between August and November depending on the region (Pombal and Morellato, 2000; Souza et al., 2004). Metrodorea nigra is often present in high population density; several authors have described its ecological importance and ability to adapt to conditions of the understory of the semideciduous seasonal forest (Durigan et al., 2000; Villela et al., 2006; Cassola, 2008). It is considered to be a key species in the nutrients dynamics of this type of forest (Villela et al., 2006) and its presence is associated with the occurrence of large late-successional trees (Durigan et al., 2000; Bertoncini, 2003; Kotchetkoff-Henriques, 2003, Cassola, 2008; Schwarcz et al., 2010). However, under conditions of fragmentation, open glades, and selective logging, the population is reduced (Bertoncini, 2003; Villela et al., 2006) or completely disappears (Cassola, 2008).

Molecular markers are powerful tools for studying genetic diversity in plant species. Simple sequence repeats (SSRs) are highly polymorphic multiallelic codominant markers that 
are particularly useful for analyzing genetic diversity within and between populations (Nybom, 2004) and frequently used to resolve the genetic relatedness of tree species (FerreiraRamos et al., 2008; Feres et al., 2009; Guidugli et al., 2012). The polymerase chain reaction (PCR) amplification of inter-simple sequence repeats (ISSRs) can be used to rapidly differentiate between closely related individuals, as well as generate a large number of highly dominant polymorphic loci (Zietkiewicz et al., 1994).

In this study, we used molecular markers to analyze the genetic diversity, structure, and historical gene flow of $3 \mathrm{M}$. nigra populations located in forest remnants located of Ribeirão Preto (SP, Brazil) for conservation purposes. We analyzed the levels of genetic diversity of juvenile and adult trees and the differences between the 2 generations. We also examined how the disturbance historical size of the forest remnants influenced genetic diversity of the species and whether the studied populations were related in the past.

\section{MATERIAL AND METHODS}

\section{Sampling and study sites}

The studied remnants were 19-20 km apart from each other in the Ribeirão Preto region

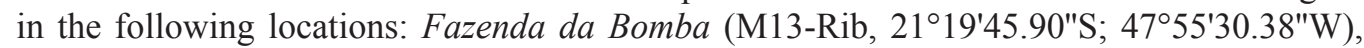
Bosque Municipal Fábio Barreto (BSQ-Rib, 21 ${ }^{\circ} 10^{\prime} 26.37^{\prime \prime}$; $47^{\circ} 48^{\prime} 1.49^{\prime \prime W}$ ), and Fazenda Águas Claras (FAC-CRAV, 21 ${ }^{\circ} 17^{\prime} 54.22^{\prime \prime} \mathrm{S} ; 47^{\circ} 40^{\prime} 28.10^{\prime \prime} \mathrm{W}$ ). They exhibit large differences in size and historic disturbance, and were likely isolated in the late 19th century, as shown in Table 1. Leaf samples tissue and GPS coordinates (GARMIN eTrex ${ }^{\circledR}$ ) were collected from 200 individuals from the 3 selected fragments (Figure 1). Individuals were classified as adults or juveniles based on the diameter at breast height $(\mathrm{DBH})$; juveniles were defined as individuals with $\mathrm{DBH}<11 \mathrm{~cm}$ and adult individuals had $\mathrm{DBH} \geq 11 \mathrm{~cm}$. At all sampling sites, the presence of several juveniles surrounding adults, forming local clusters were observed. A few isolated individuals were also found and sampled.

Table 1. Characteristics of the forest fragments evaluated.
\begin{tabular}{lcccclcll}
\hline \multicolumn{1}{l}{ Area (ha) } & N & NA & NJ & Historic & Altitude (m) & Access & Matrix \\
\hline M13-Rib & 84 & 80 & 37 & 43 & Fir/SL & 601 & Open & Sugarcane \\
BSQ-Rib & 3 & 60 & 32 & 28 & SL/Tr & 570 & Close & Urban \\
FAC-Crav & 8 & 60 & 27 & 33 & Iso & 610 & Close/Private & Sugarcane \\
\hline
\end{tabular}

Fir $=$ fires; $\mathrm{SL}=$ selective logging; $\mathrm{Tr}=$ trails; Iso $=$ isolation.

\section{DNA extraction and ISSR/SSR amplification}

Total genomic DNA was extracted from the leaves of each sampled tree using the method described by Alzate-Marin et al. (2009). Eight ISSR primers were selected from the University of British Columbia official list (UBC) (Table 2). PCR-ISSR reactions were performed in a final volume of $20 \mu \mathrm{L}$ using the GoTaq Kit (Promega, Madison, WI, USA) consisting of $8 \mu \mathrm{L} \mathrm{H}_{2} \mathrm{O}, 8 \mu \mathrm{L}$ master mix ( $400 \mathrm{nM}$ of each dNTP and $3 \mathrm{mM} \mathrm{MgCl}_{2}$ ), $2 \mathrm{mM}$ primer, and 25 ng DNA. Amplifications were performed in an Eppendorf MasterCycler thermocycler (Eppendorf, Hamburg, Germany) using the following protocol: $96^{\circ} \mathrm{C}$ for $5 \mathrm{~min}, 30$ cycles of 
denaturation at $94^{\circ} \mathrm{C}$ for $1 \mathrm{~min}$, annealing at $50^{\circ}$ for $30 \mathrm{~s}$, and extension at $72^{\circ} \mathrm{C}$ for $2 \mathrm{~min}$, and final elongation at $72^{\circ} \mathrm{C}$ for $7 \mathrm{~min}$.

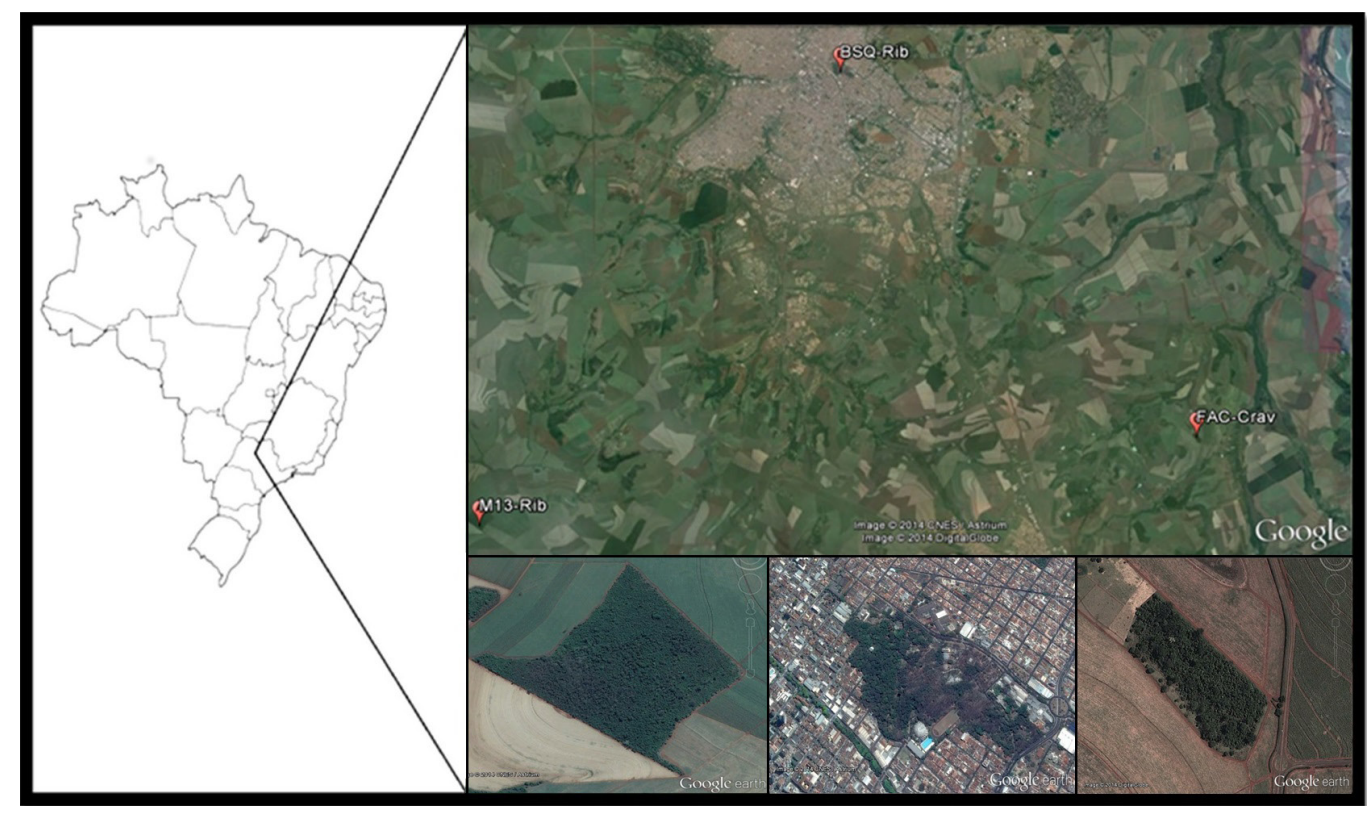

Figure 1. Forest remnants in the Ribeirão Preto region. M13-Rib (left), BSQ-Rib (center), FAC-Crav (right) (Source: Google Earth).

Table 2. Characteristics and sequence of the 8 inter-simple sequence repeat (ISSR) primers used in the genetic studies of Metrodorea nigra species.

\begin{tabular}{llcccc}
\hline Primer & Sequence & N $^{\circ}$ of loci & PL & ML & $\hat{H}_{\mathrm{E}}$ \\
\hline UBC\#1 & ACACACACACACACACT & 12 & 12 & 0 & 0.293 \\
UBC\#2 & GAGAGAGAGAGAGAGAT & 25 & 24 & 1 & 0.276 \\
UBC\#820 & GTG TGT GTG TGT GTG TC & 11 & 11 & 0 & 0.270 \\
UBC\#834 & AGA GAG AGA GAG AGA GYT & 13 & 11 & 2 & 0.299 \\
UBC\#851 & GTG TGT GTG TGT GTG TYG & 20 & 20 & 0 & 0.326 \\
UBC\#858 & TGT GTG TGT GTG TGT GRT & 24 & 24 & 0 & 0.349 \\
UBC\#860 & TGT GTG TGT GTG TGT GRA & 19 & 19 & 0 & 0.338 \\
UBC\#886 & VDV CTC TCT CTC TCT CT & 12 & 12 & 0 & 0.338 \\
\hline
\end{tabular}

$\mathrm{N}=(\mathrm{A}, \mathrm{G}, \mathrm{C}, \mathrm{T}) ; \mathrm{R}=(\mathrm{A}, \mathrm{G}) ; \mathrm{Y}=(\mathrm{C}, \mathrm{T}) ; \mathrm{B}=(\mathrm{C}, \mathrm{G}, \mathrm{T}) ; \mathrm{D}=(\mathrm{A}, \mathrm{G}, \mathrm{T}) ; \mathrm{H}=(\mathrm{A}, \mathrm{C}, \mathrm{T}) ; \mathrm{V}=(\mathrm{A}, \mathrm{C}, \mathrm{G}) ; \mathrm{Pl}=$ polymorphic loci; $\mathrm{ML}=$ monomorphic loci; $\hat{H}_{\mathrm{E}}=$ Nei genetic diversity.

Five microsatellite (SSR) primer pairs (Mtn 1, Mtn 3, Mtn 13, Mtn 16, and Mtn 19) previously developed by Guidugli et al. (2012) were used in this study. To increase the number of SSR primers available for analysis, a new set of primers was designed according to the protocol described by Guidugli et al. (2012), and 2 newly developed and highly polymorphic SSR primer pairs were obtained (Mtn 87 and Mtn 95, unpublished). All microsatellite loci were amplified by PCR in a final volume of $15 \mu \mathrm{L}$ using the GoTaq Kit (Promega) consisting of 6 
$\mu \mathrm{L} \mathrm{H}_{2} \mathrm{O}, 6 \mu \mathrm{L}$ master mix (400 nM of each dNTPs and $3 \mathrm{mM} \mathrm{MgCl}$ ), $1 \mathrm{mM}$ of each primer, and $20 \mathrm{ng}$ DNA. Amplifications were performed in an Eppendorf MasterCycler thermocycler using the following protocol: $96^{\circ} \mathrm{C}$ for $5 \mathrm{~min}, 28$ cycles of denaturation at $94^{\circ} \mathrm{C}$ for $1 \mathrm{~min}$, annealing at $50^{\circ}-60^{\circ} \mathrm{C}$ for $1 \mathrm{~min}$, and extension at $72^{\circ} \mathrm{C}$ for $1 \mathrm{~min}$, with a final elongation step at $72^{\circ} \mathrm{C}$ for $7 \mathrm{~min}$.

The PCR products were denatured and separated on $10 \%$ denaturing polyacrylamide gels, which were stained with silver nitrate. Alleles were sized by comparison to a standard 10-base pair (bp) (SSR) and 50-bp (ISSR) DNA ladder (Invitrogen, Carlsbad, CA, USA).

\section{Statistical analysis}

\section{Genetic diversity characterization}

\section{ISSR markers}

The polymorphisms obtained using ISSR were tabulated according to the presence (1) or absence (0) of bands. Each ISSR band was considered a single or bi-allelic locus, with an amplifiable allele and a null allele. The GenAlex Software 6.5 (Peakall and Smouse, 2012) was used to generate the genetic distance matrix and to calculate the Nei genetic diversity $\left(H_{\mathrm{E}}\right)$, number of alleles $\left(N_{\mathrm{A}}\right)$, effective number of alleles $\left(N_{\mathrm{E}}\right)$, and the percentage of polymorphic loci.

\section{SSR markers}

The GenAlex Software 6.5 (Peakall and Smouse, 2012) was used to calculate $N_{\mathrm{A}}$, $N_{\mathrm{E}}$, observed heterozygosity $\left(H_{\mathrm{O}}\right)$, expected heterozygosity $\left(H_{\mathrm{E}}\right)$, fixation index $(\mathrm{F})$ and probability of exclusion first (P.Ex1) and second parent (P.Ex2). Adherence to Hardy-Weinberg equilibrium was analyzed using the program GDA (Lewis and Zaykin, 2002). The frequency of null alleles and the linkage disequilibrium were analyzed using the program CERVUS 3.0 (Kalinowski et al., 2007).

To analyze the differences between means, analysis of variance, followed by Student $t$-test for each pair of means, were performed.

\section{Genetic structure}

Genetic differentiation between populations was estimated from the coefficient of gene differentiation $\left(G_{\mathrm{ST}}\right)$ (Nei, 1973) and fixation index $\left(F_{\mathrm{ST}}\right)$ (Weir and Cockerham, 1984) parameters as well as using analysis of molecular variance (AMOVA, $\Phi_{\mathrm{ST}}$ ) (Excoffier et al., 1992) using the GenAlex 6.5 software (Peakall and Smouse, 2012). The Popgene 1.31 software (Yeh et al., 1999) was used to calculate $G_{\mathrm{ST}}$ based on ISSR marker data.

\section{Ancestry and clustering analysis}

The Structure 2.0 software (Pritchard et al., 2000) was used to investigate the genetic structure and ancestry of populations from cluster analysis based on models. The method assumes the existence of a $K$ number of populations (or genetic groups), each with its own char- 
acteristic allele frequencies. The number $K$ of populations was calculated using the Bayesian inference of probability. The software infers the most probable number of groups and assigns probabilistically the sampled individuals to each of the $K$ clusters based on their genotypes. Each cluster consists of genetically similar individuals. The relationship of ancestry among individuals of the 3 populations was generated assuming a $K$ value of 1-3. For this analysis, 3 models were generated with $10^{6}$ Markov Chain Monte Carlo iterations and 30,000 Burn-in periods. The optimal value of $K$ was chosen in accordance with a previous study (Pritchard and Wen, 2003). From the matrices of genetic distance, principal coordinate analysis (PCoA) was performed using the GenAlex 6.5 (Peakall and Smouse, 2012) software. Additionally, the MEGA5 software (Tamura et al., 2011) was used to generate an unweighted pair group method with arithmetic mean dendrogram with the ISSR data.

\section{RESULTS}

\section{Genetic diversity}

\section{ISSR markers}

The 8 selected ISSR primers generated a total of 136 loci, with an average of 17 loci per primer. The number of loci per primer ranged from 11 (UBC\#820) to 25 (UBC\#2) (Table 2). The proportion of polymorphic loci ranged from $78.68 \%$ (FAC-Crav), $83.09 \%$ (BSQ-Rib), and $89.71 \%$ (M13-Rib) (Table 3). $H_{\mathrm{E}}$ was relatively high for all populations $(0.31)$. No significant differences were observed between populations of the 3 fragments, except for the number of alleles, for which the population containing the M13-Rib fragment exhibited a statistically higher value $\left(N_{\mathrm{A}}=1.88\right)$ than the others. In the analysis between generations, juveniles had slightly higher values of diversity in all 3 populations, but no significant differences were observed between generations, suggesting the absence of loss of genetic variability between generations in all population groups.

\begin{tabular}{|c|c|c|c|c|c|c|c|}
\hline & LN & PL & PPL & ML & $N_{\mathrm{A}}$ & $N_{\mathrm{E}}$ & $H_{\mathrm{E}}$ \\
\hline \multicolumn{8}{|l|}{ Population } \\
\hline M13-Rib (Adults) & 136 & 107 & $78.68 \%$ & 29 & $1.75(0.04)$ & $1.42(0.03)$ & $0.25(0.01)$ \\
\hline M13-Rib (Juveniles) & 136 & 113 & $83.09 \%$ & 23 & $1.81(0.04)$ & $1.42(0.03)$ & $0.25(0.01)$ \\
\hline BSQ-Rib (Adults) & 136 & 102 & $75 \%$ & 34 & $1.67(0.05)$ & $1.43(0.03)$ & $0.26(0.01)$ \\
\hline BSQ-Rib (Juveniles) & 136 & 107 & $78.68 \%$ & 29 & $1.7(0.05)$ & $1.43(0.03)$ & $0.26(0.01)$ \\
\hline FAC-Crav (Adults) & 136 & 99 & $72.79 \%$ & 37 & $1.60(0.06)$ & $1.36 *(0.03)$ & $0.22(0.02)$ \\
\hline FAC-Crav (Juveniles) & 136 & 102 & $75 \%$ & 34 & $1.64(0.06)$ & $1.42(0.03)$ & $0.24(0.02)$ \\
\hline P-ANOVA & - & - & - & - & 0.040 & $0.389^{\mathrm{NS}}$ & $0.407^{\mathrm{NS}}$ \\
\hline Mean & - & - & - & - & 1.707 & 1.417 & 0.249 \\
\hline \multicolumn{8}{|l|}{ Population } \\
\hline M13-Rib & 136 & 122 & $89.71 \%$ & 14 & $1.88 *(0.03)$ & $1.43(0.03)$ & $0.27(0.01)$ \\
\hline BSQ-Rib & 136 & 113 & $83.09 \%$ & 23 & $1.76(0.05)$ & $1.46(0.03)$ & $0.27(0.02)$ \\
\hline FAC-Crav & 136 & 107 & $78.68 \%$ & 29 & $1.68(0.06)$ & $1.40(0.03)$ & $0.24(0.02)$ \\
\hline P-ANOVA & - & - & - & - & 0.010 & $0.404^{\mathrm{NS}}$ & $0.370^{\mathrm{NS}}$ \\
\hline Mean & - & - & - & - & 1.777 & 1.431 & 0.260 \\
\hline
\end{tabular}

Data are reported as means $\pm \mathrm{SD} . N_{\mathrm{A}}=$ number of observed alleles; $N_{\mathrm{E}}=$ effective number of alleles; $H_{\mathrm{E}}=$ Nei's genetic diversity; $\mathrm{PL}=$ number of polymorphic loci; $\mathrm{PPL}=$ percent of polymorphic loci. ${ }^{*} \mathrm{P}<0.05$ by Student $t$-test. 


\section{SSR markers}

All 7 SSR loci exhibited polymorphisms. A total of 104 alleles were amplified with an average of 14.85, ranging from 5 (Mtn 1) to 28 (Mtn 95) (Table 4). The lowest observed heterozygosity was observed in the Mtn 1 locus (0.342) and highest in the Mtn 87 locus (0.735). Table 5 shows the diversity values obtained for all loci analyzed in the total set of individuals in each population.

Table 4. Characteristics and diversity estimates for the 7 Mtn loci.

\begin{tabular}{lcrccccccc}
\hline Locus & Range Pb & $N_{\mathrm{A}}$ & \multicolumn{1}{c}{$N_{\mathrm{E}}$} & $H_{\mathrm{O}}$ & $H_{\mathrm{E}}$ & $\mathrm{F}$ & P.Ex1 & P.Ex2 & NAF \\
\hline Mtn1* & $142-150$ & 5 & 1.790 & 0.342 & 0.441 & 0.226 & 0.226 & 0.100 \\
Mtn3* & $261-311$ & 18 & 9.380 & 0.658 & 0.893 & 0.263 & 0.784 & 0.643 \\
Mtn13* & $195-241$ & 24 & 11.727 & 0.475 & 0.915 & 0.481 & 0.830 & 0.710 \\
Mtn16* & $197-209$ & 7 & 3.889 & 0.477 & 0.743 & 0.358 & 0.520 & 0.343 \\
Mtn19* & $167-209$ & 13 & 3.068 & 0.423 & 0.674 & 0.372 & 0.491 & 0.299 \\
Mtn87** & $138-161$ & 9 & 4.491 & 0.735 & 0.777 & 0.055 & 0.576 & 0.398 \\
Mtn95** & $210-264$ & 28 & 22.043 & 0.503 & 0.955 & 0.473 & 0.908 & 0.832 \\
Total & - & 104 & - & - & - & - & 0.999 & 0.996 & 0.2256 \\
Mean & - & - & 8.05 & 0.516 & 0.771 & 0.318 & - & - & - \\
\hline
\end{tabular}

$N_{\mathrm{A}}=$ number of alleles; $N_{\mathrm{E}}=$ effective number of alleles; $H_{\mathrm{O}}=$ observed heterozygosity; $H_{\mathrm{E}}=$ expected heterozygosity; $\mathrm{F}$ = fixation index; P.Ex1 = probability of exclusion for the first parental individual; P.Ex2 = probability of exclusion for the second parental individual; NAF $=$ null alleles frequency. *Primers from Guidugli et al. (2012). **Unpublished.

Table 5. Genetic diversity in 3 populations of Metrodorea nigra analyzed using simple sequence repeat (SSR) markers.

\begin{tabular}{|c|c|c|c|c|c|c|c|}
\hline & $\mathrm{N}$ & $\mathrm{K}$ & $N_{\mathrm{E}}$ & $H_{\mathrm{O}}$ & $H_{\mathrm{E}}$ & $\mathrm{F}$ & CI-F \\
\hline \multicolumn{8}{|l|}{ Population } \\
\hline M13-Rib (Adults) & 37 & 66 & $5.397(1.44)$ & $0.516(0.09)$ & $0.695(0.09)$ & $0.265(0.08)$ & $0.222-0.319$ \\
\hline M13-Rib (Juveniles) & 43 & 68 & $5.864(1.81)$ & $0.509(0.09)$ & $0.703(0.09)$ & $0.305(0.08)$ & $0.254-0.343$ \\
\hline BSQ-Rib (Adults) & 32 & 62 & $6.056(1.64)$ & $0.508(0.06)$ & $0.759(0.06)$ & $0.330(0.06)$ & $0.288-0.375$ \\
\hline BSQ-Rib (Juveniles) & 28 & 69 & $5.960(1.26)$ & $0.522(0.07)$ & $0.748(0.06)$ & $0.307(0.07)$ & $0.266-0.367$ \\
\hline FAC-Crav (Adults) & 27 & 55 & $4.82(1.25)$ & $0.493(0.09)$ & $0.659(0.1)$ & $0.185(0.12)$ & $0.091-0.237$ \\
\hline FAC-Crav (Juveniles) & 33 & 63 & $4.958(1.32)$ & $0.539(0.07)$ & $0.695(0.08)$ & $0.159(0.13)$ & $0.072-0.225$ \\
\hline P-ANOVA & - & - & $0.987^{\mathrm{NS}}$ & $0.999^{\mathrm{NS}}$ & $0.955^{\mathrm{NS}}$ & $0.718^{\mathrm{NS}}$ & - \\
\hline Mean & - & 63.8 & 5.509 & 0.515 & 0.710 & 0.259 & - \\
\hline \multicolumn{8}{|l|}{ Population } \\
\hline M13-Rib & 80 & 76 & $6.02(1.87)$ & $0.513(0.09)$ & $0.704(0.09)$ & $0.291(0.08)$ & $0.245-0.336$ \\
\hline BSQ-Rib & 60 & 80 & $6.73(2.05)$ & $0.515(0.06)$ & $0.765(0.06)$ & $0.329(0.07)$ & $0.285-0.382$ \\
\hline FAC-Crav & 60 & 72 & $5.444(1.66)$ & $0.519(0.08)$ & $0.688(0.09)$ & $0.180(0.12)$ & $0.090-0.237$ \\
\hline P-ANOVA & - & - & $0.889^{\mathrm{NS}}$ & $0.999^{\mathrm{NS}}$ & $0.777^{\mathrm{NS}}$ & $0.500^{\mathrm{NS}}$ & - \\
\hline Mean & - & 76 & 6.065 & 0.515 & 0.719 & 0.267 & - \\
\hline
\end{tabular}

$\mathrm{N}=$ number of individuals, $\mathrm{K}=$ total number of alleles; $N_{\mathrm{A}}=$ number of alleles; $N_{\mathrm{E}}=$ effective number of alleles; $H_{\mathrm{O}}=$ observed heterozygosity; $H_{\mathrm{E}}=$ expected heterozygosity; $\mathrm{F}=$ fixation index; CI-F = Jackknife confidence intervals for the fixation index. $N_{\mathrm{A}}, H_{\mathrm{E}}, H_{\mathrm{E}}$ and $\mathrm{F}$ are reported as means $\pm \mathrm{SD}$.

For all loci except Mtn87, the genotype frequencies showed significant deviations from Hardy-Weinberg equilibrium. Analysis of individual populations revealed that FAC-Crav population had only 3 loci (Mtn 3, Mtn 13, and Mtn 95) that significantly deviated from HardyWeinberg equilibrium, while the M13-Rib and Rib BSQ populations contained 6 loci with significant deviations. Pairwise comparisons among loci did not indicate linkage disequilibrium after applying Bonferroni correction $(99 \%, \alpha=0.01)$ for multiple comparisons, except for the Mtn 16 x Mtn 95 pair. These results suggest that these loci are suitable for parentage analysis. 
A different total number of alleles $(\mathrm{K})$ was observed in the sample sets. The lowest value was observed among juveniles in the FAC-Crav population $(\mathrm{K}=55)$ and the highest among juveniles in the BSQ-Rib $(\mathrm{K}=69)$ population. For whole populations, the value of $\mathrm{K}$ ranged from 72 (FAC-Crav) to 80 (BSQ-Rib). There were no significant differences between the effective number of alleles of the populations. Populations exhibited high values of $H_{\mathrm{O}}$ and $H_{\mathrm{E}}$ $\left(H_{\mathrm{O}}=0.515, H_{\mathrm{E}}=0.765\right.$, Rib-BSQ; $H_{\mathrm{O}}=0.513, H_{\mathrm{E}}=0.704, \mathrm{M} 13-\mathrm{Rib} ; H_{\mathrm{O}}=0.513, H_{\mathrm{E}}=0.688$, FAC-Crav); however, no significant differences between sample sets were observed. The value of $\mathrm{F}$ was positive and differed from zero for all populations, indicating heterozygote deficiency, likely because of inbreeding, or the presence of null alleles, whose frequency per locus is shown in Table 4. Lower values of F were observed in FAC-Crav (0.180) and the highest population in the BSQ-Rib (0.329); however, the differences were not statistically significant.

\section{Genetic structure}

The genetic structure of populations of the 3 fragments was evaluated using 2 different methodologies in this study. According to AMOVA, most genetic variability was found within populations. ISSR analysis indicated a higher value $\left(\Phi_{\mathrm{ST}}=0.27\right)$ than the analysis using SSR markers $\left(\Phi_{\mathrm{ST}}=0.13\right)$. The $\mathrm{F}$ statistics analysis indicated low differentiation between populations (ISSR: $G_{\mathrm{ST}} 0.159$; SSR: $0.062 G_{\mathrm{ST}}$ and $F_{\mathrm{ST}} 0.062$ ), and a high value of historical gene flow between fragments (ISSR-Nm $=2.633$; SSR-Nm $=7.510$ ) (Tables 6 and 7).

\begin{tabular}{|c|c|c|c|c|}
\hline Values & df & SS & EV & $\% *$ \\
\hline \multicolumn{5}{|l|}{ ISSR markers } \\
\hline Between populations, $\Phi_{\mathrm{ST}}$ & 2 & 811.881 & 5.912 & $27 \%$ \\
\hline Within populations, $\Phi_{\text {CT }}$ & 197 & 3103.333 & 15.753 & $73 \%$ \\
\hline Total & 199 & 3915.214 & 21.665 & $100 \%$ \\
\hline \multicolumn{5}{|l|}{ SSR markers } \\
\hline Between populations, $\Phi_{\mathrm{ST}}$ & 2 & 144.760 & 0.994 & $13 \%$ \\
\hline Within populations, $\Phi_{\text {Ст }}$ & 197 & 1330.600 & 6.754 & $87 \%$ \\
\hline Total & 199 & 1475.360 & 7.749 & $100 \%$ \\
\hline
\end{tabular}

$\mathrm{df}=$ degrees of freedom; $\mathrm{SS}=$ sum of squares; $\mathrm{EV}=$ estimated variance; $\%=$ percent of the total variance. $* \mathrm{P}<$ 0.001 .

Table 7. Genetic structure of the 3 Metrodorea nigra populations.

\begin{tabular}{|c|c|c|c|c|c|}
\hline & $H_{\mathrm{t}}$ & $H_{\mathrm{s}}$ & $G_{\mathrm{ST}}$ & $F_{\mathrm{ST}}$ & $N_{\mathrm{m}}$ \\
\hline \multicolumn{6}{|l|}{ ISSR markers } \\
\hline Mean & 0.309 & 0.259 & 0.159 & - & 2.633 \\
\hline Standard deviation & 0.024 & 0.019 & - & - & - \\
\hline \multicolumn{6}{|l|}{ SSR markers } \\
\hline Mean & 0.772 & 0.719 & 0.062 & 0.062 & 7.510 \\
\hline Standard deviation & 0.066 & 0.068 & - & - & \\
\hline
\end{tabular}

$H_{\mathrm{t}}=$ total genetic heterozygosity; $H_{\mathrm{s}}=$ mean heterozygosity within population; $F_{\mathrm{ST}}=$ Weir and Cockerham (1984) coefficient of population differentiation; $G_{\mathrm{ST}}=\operatorname{Nei}(1973)$ coefficient of population differentiation; $N_{\mathrm{m}}=$ allelic flow.

The FAC-Crav and BSQ-Rib populations showed greater genetic similarity to each other than compared to the M13-Rib population, with higher values of genetic similarity obtained using ISSR (Table 8). 
Table 8. Nei's genetic identity (1978) (above diagonal) and geographic distances between the fragments (km) (below diagonal).

\begin{tabular}{lccc}
\hline Pop ID & M13-Rib & BSQ-Rib & FAC-Crav \\
\hline ISSR markers & & & \\
M13-Rib & - & 0.8874 & 0.8938 \\
BSQ-Rib & 21.25 & - & 0.9263 \\
FAC-Crav & 26.25 & 19.10 & - \\
SSR markers & - & 0.694 & 0.708 \\
M13-Rib & 21.25 & - & 0.758 \\
BSQ-Rib & 26.25 & 19.10 & - \\
FAC-Crav & & & \\
\hline
\end{tabular}

\section{Ancestry and clustering analysis}

Ancestry analysis suggested that the studied populations could be divided into 3 genetic clusters. Of the 3 scenarios evaluated, the model assigned a value of $\mathrm{K}=3$ showed the highest logarithmic probability $[\log \mathrm{P}(\mathrm{X} \mid \mathrm{K})]$ in analysis with both markers. The obtained average values of $\alpha$ suggest low mixing between the 3 populations (ISSR, $\alpha=0.0312$ and SSR, $\alpha=0.0557$ ). The most "pure" population was from the FAC-Crav fragment, which displayed the highest proportions of genetic composition of a single cluster. The population showing the highest genetic mixing was the BSQ-Rib population; this result was most clearly observed in the analysis using SSR markers (Figure 2).

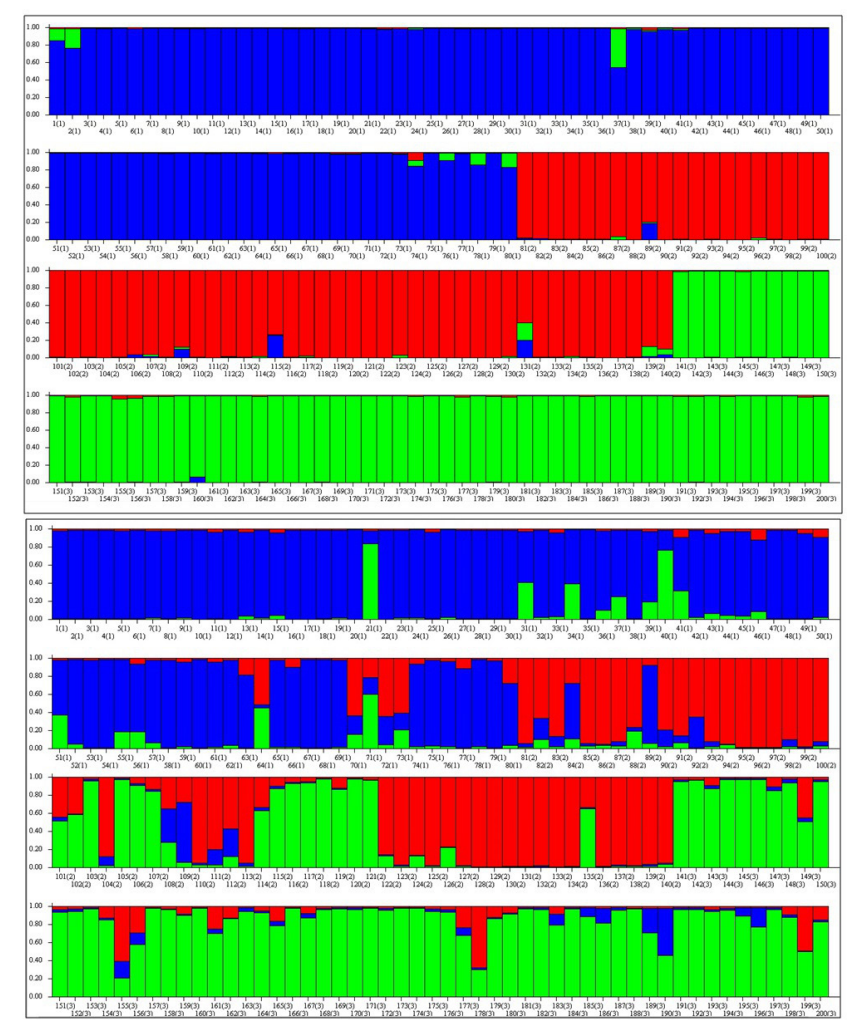

Figure 2. Ancestry of the three Metrodorea nigra populations accessed by ISSR markers (above) and SSR markers (below). In both analyses, (1) = M13-Rib; (2) = BSQ-Rib; (3) = FAC-Crav. 
PCoA (Figure 3) and the unweighted pair group method with arithmetic mean dendrogram generated using data obtained with ISSR (Figure 4) showed that the 3 populations formed separate groups. PCoA analysis was used to investigate the relative position of the population in a multidimensional space. Most of the variance was divided between the 2 first coordinates (38.89 and 21.77\%). A scatter plot of these 2 coordinates clearly separated the 3 populations and illustrated absence of fully differentiated sub-populations within them.

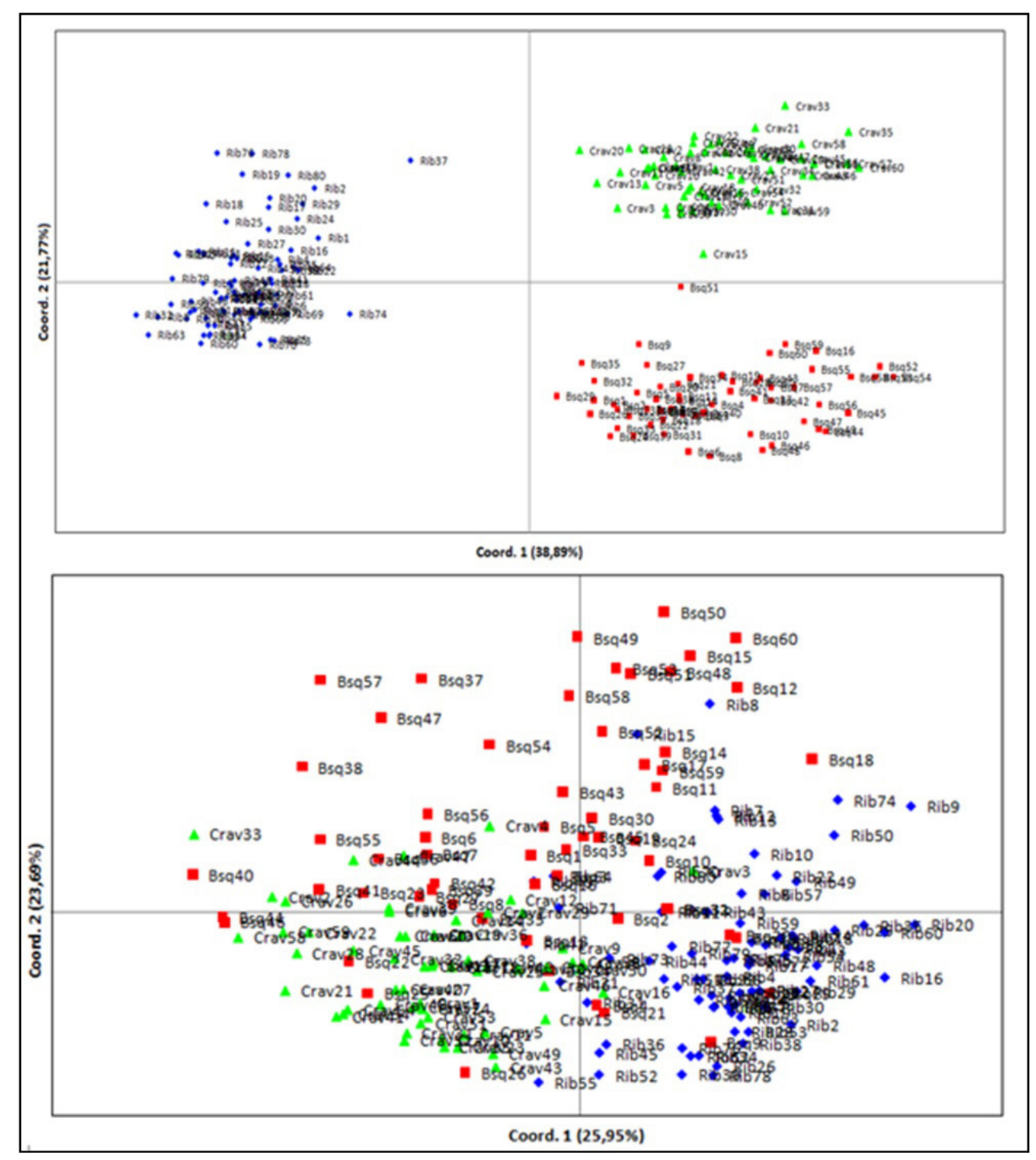

Figure 3. Principal Coordinates Analysis (PCoA) for the three populations with ISSR markers (above) and SSR markers (below). Crav $=$ FAC-Crav; Rib $=$ M13-Rib; Bsq = BSQ-Rib. 


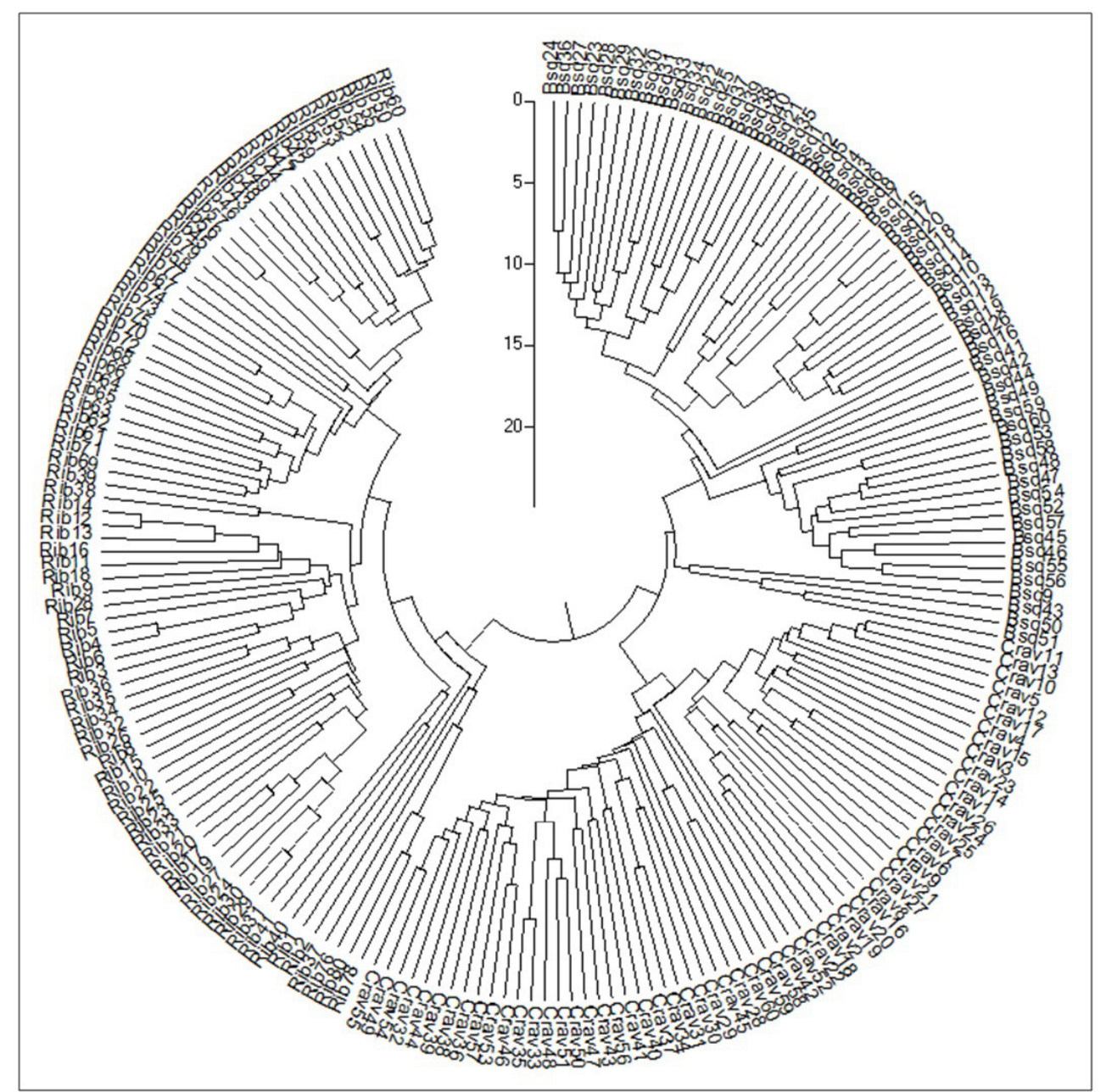

Figure 4. UPGMA dendrogram generated with ISSR markers for the 200 Metrodorea nigra individuals. Crav $=$ FAC-Crav; Rib = M13-Rib; Bsq = BSQ-Rib.

When the PCoA analysis was performed using data from SSR markers, the results generally revealed separation between populations. However, in the center of the graph, individuals in the 3 groups were mixed, indicating high similarity between them. Divergence between the analysis of the 2 markers was likely because of the smaller number of loci analyzed using SSR markers (only 7), despite that these markers were more informative.

\section{DISCUSSION}

\section{Genetic diversity}

Despite the differences in size and history of the 3 fragments examined in this study (FAC-Crav, BSQ-Rib, M13-Rib), all M. nigra populations exhibited high values of polymor- 
phism and genetic diversity with both molecular markers, which were efficient for differentiating the 200 sampled individuals. A smaller percentage of polymorphic loci and number of alleles were observed in the FAC-Crav and BSQ-Rib populations compared to the M13-Rib population, but none of the other parameters evaluated were statistically different between the 3 population groups, indicating that habitat reduction has little effect on the genetic variability of $M$. nigra.

No individual clone was identified. Despite the smaller size (3 ha), the BSQ-Rib fragment exhibited a larger number of alleles, indicating that the population had the highest genetic variability among the individuals analyzed. However, the population also exhibited a high value for F, indicating high deficiency of heterozygotes for this sample set. According to Nybom (2004), a deficiency in heterozygotes observed in the microsatellite analyses may have been caused by the presence of null alleles within the studied loci.

The FAC-Crav population showed the lowest fixation index. Although small fragments generally show low values of diversity, the fragment FAC-Crav ( 8 ha) had a better conservation history and was more protected from disturbance than the BSQ-Rib and M13-Rib fragments.

No statistical differences between the diversity indices of the 2 generations were observed in the 3 populations using SSR analysis. Schwarcz et al. (2010) found values of $H_{\mathrm{O}}$ and $H_{\mathrm{E}}$ of 0.633 and 0.224 , respectively, in natural populations of M. nigra in the São Paulo State using allozyme markers. These values were much lower than those found in the present study. However, allozymes generally exhibit lower polymorphism and smaller number of alleles than SSR markers, which may explain these differences. Similarly, F (0.641) was well above the values found in the 3 populations in the present analysis. These authors also found no significant differences between generations of adults and juveniles, or between populations of fragments of different sizes, which is a strong indication of the species' tolerance to the effects of fragmentation and habitat reduction.

The genetic diversity observed in M. nigra is in contrast with those expected for populations in small forest fragments, which often have lower genetic diversity and allelic richness because of genetic drift and increased inbreeding (Lowe et al., 2005). High levels of genetic diversity in fragmented natural populations have also been reported in many tropical species such as Caesalpinia echinata (Cardoso et al., 1998), Acrocomia aculeata (Oliveira et al., 2012), Trichilia pallida (Zimback et al., 2004), and Cariniana estrellensis (Guidugli, 2011).

The polymorphism values obtained from ISSR analysis were similar to those observed by Zimback et al. (2004) (90.3-97.3\%) in populations of Trichilia pallida and by Zhang et al. (2013) (84-90\%) in natural populations of Larix gmelinii.

The average number of alleles per SSR locus found in this study (14.85) was similar to those observed in other tropical tree species such as Eugenia uniflora (14.4; Ferreira-Ramos et al., 2008) and Euterpe edulis (14.7; Conte et al, 2006). The index of genetic diversity in $M$. nigra $\left(H_{\mathrm{E}}=0.771\right)$ was consistent with those observed in other Brazilian forest species, including Cariniana legalis (0.721; Leal et al., 2014), E. edulis (0.781; Conte et al., 2006.), E. uniflora (0.83; Ferreira-Ramos et al., 2008), and Manilkara huberi (0.86; Azevedo et al., 2007).

Thus, both the ISSR and SSR methods were effective for studying the genetic diversity of the forest species M. nigra, showing similar results for all analyzed aspects.

\section{Genetic structure}

Estimates of genetic differentiation between populations using dominant markers are often found by using the $G_{\mathrm{ST}}$ parameter according to Nei (1973) or AMOVA $\left(\Phi_{\mathrm{ST}}\right)$. In studies 
using ISSR, the mean values of the 2 estimators are typically quite similar. For studies using microsatellite markers, population differentiation is generally estimated using $F_{\mathrm{ST}}$ (Weir and Cockerham, 1984) and $G_{\mathrm{ST}}$ (Nybom, 2004).

The results of analysis using ISSR markers showed greater genetic differentiation among populations than those obtained using SSR markers with AMOVA and both $G_{\mathrm{ST}}$ and $F_{\mathrm{ST}}$ parameters. Despite these differences, both markers suggest that there is reasonable differentiation between populations, although most of the genetic variability is distributed within populations.

Metrodorea nigra is described as a self-incompatible allogamous species, with barochoric seed dispersal. Its main pollinators include flies of the Muscidae and Fanniidae families which are attracted by the characteristic unpleasant odor of their flowers (Pombal and Morellato, 2000; Souza et al., 2008). Outcrossing species and particularly tree species exhibit the highest genetic diversity within their populations (Hamrick, 1990). The $G_{\mathrm{ST}}$ values observed in this study (ISSR- $G_{\mathrm{ST}}=0.159 ;$ SSR- $G_{\mathrm{ST}}=0.062$ ) agreed with those expected for outcrossing species $\left(G_{\mathrm{ST}}<19 \%\right)$ (Hamrick and Godt, 1996). The high values of $N_{\mathrm{m}}$ were also in agreement with those expected for tropical trees (Reis, 1996), suggesting, despite that their isolation, the occurrence of strong historical gene flow between the 3 populations occurred, indicating a connection in the past.

\section{Ancestry and clustering analysis}

The ancestry analysis corroborated the results of unweighted pair group method with arithmetic mean cluster analysis and PCoA by assigning each of the 3 populations at a distinct genetic cluster. The $\alpha$ values observed in the analyses using both markers indicated low genetic mixing between populations. According to Falush et al. (2003), $\alpha$ values greater than 1 indicate high genetic homogeneity and those near 0 indicate genetic differentiation values. The values obtained using ISSR (0.0312) were lower than those obtained using SSR markers (0.0557). This indicates that these markers show high resolution for differentiating individuals within populations, which is likely because of the higher number of loci obtained using this technique, despite its lower informativeness. The results obtained using both markers agreed with for the expected values for autochorous pollinating species and potential short pollen dispersal, maintaining the current reproductive isolation between the 3 populations.

\section{CONCLUSIONS}

Our results suggest that habitat reduction has little effect on the genetic variability of M. nigra, and larger fragments do not necessarily contain populations with greater genetic diversity. No differences between generations of adults and juveniles were observed in any of the 3 populations, indicating that the current pressures did not alter the genetic composition of the populations studied. However, the long-term effects of fragmentation and isolation of these fragments are difficult to predict. The observed high-density occurrence of the species indicates that the 3 remnants still possesses great conservation value, despite the small area and habitat disturbance. Isolation of the populations analyzed likely dates from the mid-19th century, when a large amount of native forest in the region was suppressed. Ancestry and cluster analysis showed that the 3 populations were likely connected in the past, given the high values of historical gene flow, but also showed a reasonable level of differentiation. 
A more accurate conclusion regarding the habitat loss effects on forest species requires additional studies with a greater number of forest remnants of different sizes and historic of conservation.

\section{ACKNOWLEDGMENTS}

Research supported by a grant from São Paulo State Government to A.L. AlzateMarin: FAPESP (\#13/01265-8). We also acknowledge the support of Pró-Reitoria de Pesquisa of Universidade de São Paulo and CAPES-PROEX grants. R.M. Moraes Filho was supported by a doctoral fellowship from CAPES and F. Bonifácio-Anacleto was supported by CNPq (\#IC-134699/2012-2) and FAPESP (\#TTIII-2013/18633-0) fellowship. A.L. Alzate-Marin was supported by a research assistantship from CNPq (PD Senior \#150277/2009-1, PV \#300140/2011-8). The authors would like to thank Dr. Alison G. Nazareno for invaluable scientific support in primer development. The authors thank Dr. Alexandre Carvalho Gouvêa (Chefe Seção Bosque Zoológico Municipal Ribeirão Preto/SP) by authorization for sample collection, Dra.Olga Kotchetkoff-Henriques (Prefeitura Municipal Ribeirão Preto/SP) for sharing part of your extensive knowledge with the group and for collaboration in the sample collections. We also thank Ronai Ferreira-Ramos and Gabriel Machado for collaboration regarding sample collections.

\section{REFERENCES}

Aguilar R, Quesada M, Ashworth L, Herrerias-Diego Y, et al. (2008). Genetic consequences of habitat fragmentation in plant populations: susceptible signals in plant traits and methodological approaches. Mol. Ecol. 17: 5177-5188.

Alzate-Marin AL, Guidugli MC, Soriani HH and Martinez CA (2009). An efficient and rapid DNA minipreparation procedure suitable for PCR/SSR and RAPD analyses in tropical forest tree species. Braz. Arch. Biol. Technol. 52: 1217-1224.

Andrén H (1994). Effects of habitat fragmentation on birds and mammals in landscapes with different proportions of suitable habitat: a review. Oikos 71: 355-366.

Azevedo VC, Kanashiro M, Ciampi AY and Grattapaglia D (2007). Genetic structure and mating system of Manilkara huberi (Ducke) A. Chev., a heavily logged Amazonian timber species. J. Hered. 98: 646-654.

Bertoncini AP (2003). Estrutura e Dinâmica de uma Área Perturbada na Terra Indígena Araribá, Avaí-SP: Implicações para o Manejo e a Restauração Florestal. Doctoral thesis, Instituto de Biologia. Universidade Estadual de Campinas, Campinas, 162.

Cardoso MA, Provan J, Powell W and Ferreira PCG (1998). High genetic differentiation among remnant populations of the endangered Caesalpinia echinata Lam. (Leguminosae Caesalpinioideae). Mol. Ecol. 7: 601-608.

Cassola H (2008). Aspectos da Estrutura Fitossociológica e Silvigenética em Fragmentos de Floresta Estacional Semidecídua com Diferentes Histórias de Perturbação em Botucatu, SP. 86f. Master's thesis, Universidade de São Paulo, Escola Superior de Agricultura "Luiz de Queiroz”. Available at [www.teses.usp.br/teses/disponiveis/11/11150/ tde-16072008-121520/publico/heloizacassola.PDF]. Accessed October 7, 2014, Piracicaba.

Conte R, dos Reis MS and Vencovsky R (2006). Effects of management on the genetic structure of Euterpe edulis Mart. populations based on microsatellites. Sci. Forestalis 72: 81-88.

Durigan G, Franco GADC, Saito M and Baitello JB (2000). Estrutura e diversidade do componente arbóreo da floresta na Estação Ecológica dos Caetetus, Gália, SP. Rev. Bras. Bot. 23: 371-383.

Excoffier L, Smouse PE and Quattro JM (1992). Analysis of molecular variance inferred from metric distances among DNA haplotypes: application to human mitochondrial DNA restriction data. Genetics 131: 479-491.

Falush D, Stephens M and Pritchard JK (2003). Inference of population structure using multilocus genotype data: linked loci and correlated allele frequencies. Genetics 164: 1567-1587.

Feres JM, Guidugli MC, Mestriner MA and Sebbenn AM (2009). Microsatellite diversity and effective population size in a germplasm bank of Hymenaea courbaril L. var stilbocarpa (Leguminosae), an endangered tropical tree: recommendations for conservation. Genet. Resour. Crop Evol. 56: 797-807. 
Ferreira-Ramos R, Laborda PR, Santos MO and Mayor MS (2008). Genetic analyses of forest species Eugenia uniflora L. through of newly developed SSR markers. Conserv. Genet. 9: 1281-1285.

Guidugli MC (2011). Estudos Genéticos da Espécie Florestal Cariniana strellensis (Raddi) Kuntez: Diversidade, Sistema de Cruzamento e Fluxo Gênico Contemporâneo. Doctoral thesis, Faculdade de Medicina de Ribeirão Preto, Universidade de São Paulo. Available at [www.teses.usp.br/teses/disponiveis/17/17135/tde-19012012-163618/ publico/DoutoradoMarcelaCorboGuidugli.pdf]. Accessed October 7, 2014. Ribeirão Preto, 170.

Guidugli MC, Ferreira-Ramos R, de Sousa AC, Cidade FW, et al. (2012). Genetic diversity of Metrodorea nigra (Rutaceae) from a small forest remnant in Brazil assessed with microsatellite markers. Genet. Mol. Res. 11: 10-16.

Hamrick JL (1990). Isozymes and the Analysis of Genetic Structure in Plant Populations. In: Isozymes in Plant Biology (Soltis DE and Soltis PS, eds.). Chapman \& Hall, London, 87-105.

Hamrick JL and Godt MJW (1996). Effects of life history traits on genetic diversity in plant species. Philos. Trans. R. Soc. Lond. Biol. Sci. 351: 1291-1298.

Kalinowski ST, Taper ML and Marshall TC (2007). Revising how the computer program CERVUS accommodates genotyping error increases success in paternity assignment. Mol. Ecol. 16: 1099-1106.

Kotchetkoff-Henriques O (2003). Characterization of the Natural Vegetation in Ribeirão Preto, SP: Bases for Conservation. Doctoral thesis, Faculdade de Filosofia, Ciências e Letras de Ribeirão Preto, Universidade de São Paulo, Ribeirão Preto.

Leal JB, Santos RP and Gaiotto FA (2014). Effect of selective logging on genetic diversity and gene flow in Cariniana legalis sampled from a cacao agroforestry system. Genet. Mol. Res. 13: 626-635.

Lewis PO and Zaykin D (2002). Genetic Data Analysis: Computer Program for the Analysis of Allelic Data. Available at [http://www.eeb.uconn.edu/people/plewis/downloads/gda-1.1.win32.zip]. Accessed October 7, 2014.

Lowe AJ, Boshier D, Ward M, Bacles CF, et al. (2005). Genetic resource impacts of habitat loss and degradation; reconciling empirical evidence and predicted theory for neotropical trees. Heredity 95: 255-273.

Morellato LPC and Haddad CFB (2000). Introduction: the Brazilian Atlantic Forest. Biotropica 32: 786-792.

Nei M (1973). Analysis of gene diversity in subdivided populations. Proc. Natl. Acad. Sci. U. S. A. 70: 3321-3323.

Nybom H (2004). Comparison of different nuclear DNA markers for estimating intraspecific genetic diversity in plants. Mol. Ecol. 13: 1143-1155.

Oliveira DA, Melo Junior AF, Brandao MM, Rodrigues LA, et al. (2012). Genetic diversity in populations of Acrocomia aculeata (Arecaceae) in the northern region of Minas Gerais, Brazil. Genet. Mol. Res. 11: 531-538.

Peakall R and Smouse PE (2012). GenAlEx 6.5: Genetic Analysis in Excel. Population Genetic Software for Teaching and Research-an Update. Bioinformatics Available at [http://bioinformatics.oxfordjournals.org/content/early/2012/07/20/ bioinformatics.bts460.full.pdf]. Accessed October 7, 2014.

Pombal ECP and Morellato LPC (2000). Differentiation of floral color and odor in two fly pollinated species of Metrodorea (Rutaceae) from Brazil. Plant Syst. Evol. 221: 141-156.

Pritchard JK and Wen W (2003). Documentation for STRUCTURE Software: Version 2. Available at [http://pritchardlab. stanford.edu/home.html]. Accessed April 20, 2014.

Pritchard JK, Stephens M and Donnelly P (2000). Inference of population structure using multilocus genotype data. Genetics 155: 945-959.

Reis MS (1996). Dinâmica da movimentação dos alelos: subsídios para conservação e manejo de populaçõeses naturais em plantas. Braz. J. Genet. 19: 37-47.

Ribeiro MC, Metzger JP, Martensen AC and Ponzoni FJ (2009). The Brazilian Atlantic Forest: how much is left, and how is the remaining forest distributed? Implications for conservation. Biol. Cons. 142: 1141-1153.

Schwarcz KD, Pataca CL, Abreu AG and Bariani JM (2010). Genetic diversity in Atlantic Forest trees: fragmentation effects on Astronium graveolens (Anacardiaceae) and Metrodorea nigra (Rutaceae), species with distinct seed dispersal strategies. Bot. J. Linnean Soc. 164: 326-336.

Souza LA, Moscheta IS, Mourão KSM and Rosa SM (2004). Morphology and anatomy of the flower and anthesis of Metrodorea nigra St. Hill. (Rutaceae). Braz. Arch. Biol. Technol. 47: 107-112.

Souza LA, Rosa SM and Moscheta IS (2008). Anatomy of the developing fruit of Metrodorea nigra A. St.-Hil. (Rutaceae). Braz. Arch. Biol. Technol. 51: 1171-1179.

Tamura K, Peterson D, Peterson N, Stecher G, et al. (2011). MEGA5: molecular evolutionary genetics analysis using maximum likelihood, evolutionary distance, and maximum parsimony methods. Mol. Biol. Evol. 28: 2731-2739.

Villela DM, Nascimento MT, Aragão LEOC and Gama DM (2006). Effect of selective logging on forest structure and nutrient cycling in a seasonally dry Brazilian Atlantic forest. J. Biogeogr. 33: 506-516.

Weir BS and Cockerham CC (1984). Estimating F-statistics for the analysis of population-structure. Evolution 38: 13581370.

Yeh FC, Yang RC and Boyle T (1999). POPGEN, Version 1.31. Microsoft Windows-Based Freeware for Population 
Genetic Analysis. University of Alberta/CIFOR, Edmonton.

Zhang L, Zhang HG and Li XF (2013). Analysis of genetic diversity in Larix gmelinii (Pinaceae) with RAPD and ISSR markers. Genet. Mol. Res. 12: 196-207.

Zietkiewicz E, Rafalski A and Labuda D (1994). Genome fingerprinting by simple sequence repeat (SSR)-anchored polymerase chain reaction amplification. Genomics 20: 176-183.

Zimback L, Mori ES, Kageyama PY and Veiga RFA (2004). Estrutura genética de populações de Trichilia pallida Swartz (Meliaceae) por marcadores RAPD. Sci. Forest 65: 114-119. 